\title{
Early Warning Systems of Currency Crises: An Empirical Investigation in Vietnam
}

\author{
VO THI THUY ANH \\ The University of Danang - University of Economics - vothuyanh@due.edu.vn \\ TRAN NGUYEN TRAM ANH \\ The University of Danang - University of Economics - anhtnt@ due.edu.vn \\ HA XUAN THUY \\ The University of Danang - University of Economics - thuyhx91@ gmail.com
}

\section{ARTICLE INFO ABSTRACT}

Article history:

Received:

Apr. 12, 2016

Received in revised form:

May 30, 2016

Accepted:

Sep. 23, 2016

Keywords:

Currency crisis, finance, early warning system.
Based on the study of Kaminsky and Reinhart (1999), this paper studies and applies early warning systems of currency crises to the case of Vietnam from 1996 to 2014. Its results show that the currency crisis is signaled six times during the observed period. Several principal indicators of the currency crisis in Vietnam include increased import, decreased export, excess real M1 balances, low international reserves and deposit growth, high interest rate and credit growth, high domestic-foreign rate differential, and decreased real output. Hence, the Government and the State Bank of Vietnam should grant appropriate policies not only to control the money supply and interest rate, but also to stimulate the ability of capital mobilization of Vietnam's banking system and to facilitate export activities in the coming years. 


\section{Problem statement}

Currency crises have occurred in different places of the world over the past two decades, especially the 1996-1997 period and these recent years, which arouses concern of both economic analysts and policy makers. To date, there have been four generation currency crisis models. While the macro factors are accentuated in first- and secondgeneration models, third-generation ones attempt to interpret the matters involving the Asian crises during 1996-1997 with the highlights of moral hazard and imperfect information (Krugman, 1998; Corsetti et al., 1999) or self-fulfilling expectations (Chang \& Velasco, 1998, 2001). Johnson et al. (2000) documented that corporate governance, specifically the effectiveness of protection for shareholders in the minority, helps clarify the depreciation of exchange rate and stock market slump more efficiently than typical macroeconomic parameters, marking other newly introduced fourth-generation models.

From different theoretical frameworks, various empirical studies have been conducted with two fundamental approaches: parametric and nonparametric estimators. The former is strongly contingent on probit/logit models, whereas Kaminski and Reinhart's (1999) theory is based largely upon concerning the latter approach. The primary concept of the nonparametric estimation is whether there exists any abnormality of key economic variables before an impending crisis, thereby allowing for identification of the factors contributing to financial crises.

In this paper and on the basis of incorporating the models of four generations and nonparametric approach, we conceptualize the impact of macro variables on currency instability in Vietnam with a few implications for mitigating the problem.

One contribution of this paper is that it addresses the phases indicative of the currency crisis and the signals of these periods. The fluctuations of these could be considered in policy-making effort for appropriate intervention.

\section{Literature review}

\subsection{Theoretical research}

Studies on financial crisis with an emphasis on currency crisis provided explanations for the causes of such phenomenon in different countries. These models can be grouped into four generations as below: 
One of the first-generation models was developed by Krugman (1979), who analyzed the crises that occurred in Latin America in the 60s and 70s and focused on the effects of fiscal policy and monetary environment on the balance-of-payments crisis under the pegged exchange rate regime. When the economy is down, many countries issue money to cover budget deficit, and the central bank are obliged to sell foreign exchange reserves to maintain a target level of exchange rate. However, during a reduction in the national foreign exchange reserves, speculators could predict the collapse of the pegged exchange rate regime, undertaking a conversion of domestic currency into foreign currency in order to evade capital losses.

Second-generation models appeared after the 1992-1993 currency crisis in the European Monetary System and the crisis in Mexico between 1994 and 1995. Initiated in the study of Obstfeld (1986), these took into account the government's policy options to defend the exchange rate and associated costs, and also from this approach the author validated self-fulfilling expectations, implying that market equilibrium depends on investors' expectations and their activities and arguing for the possible existence of a good many of equilibria. Monetary policy and fiscal policy are assumed to be exogenous factors. Still, the causes of expected changes are not fully explained in the model of this generation, except for the fact they are addressed through basic elements.

Only after the crises in Latin American countries in the 80s, Nordic countries in 1992, and Southeast Asian countries in 1997 did third-generation models become widely known. Examining a combination of impacts of moral hazard and information asymmetry as well as crowd and spillover effects on the currency crisis, these models indicated that several factors, such as overheating, asset prices, international capital flows, and regulations on the operations of financial institutions, might be employed to predict the problem (Heun \& Schilink, 2004). Kaminsky and Reinhart (1999), using a dataset of 76 currency crises and 27 banking crises, concluded that the currency and banking crises are closely associated during financial liberalization. Commonly, banking sector trouble was recorded ahead of the currency crisis.

Breuer (2004) also synthesized research on currency and banking crises, considering different models as well as the role of institutions and classifying them as fourthgeneration models, including those of Johnson et al. (2000) and Acemoglu et al. (2002). Accentuated by these models are financial and economic rules and regulations, shareholder rights, transparency and monitoring of the financial system and the 
government's shortcomings, origin of law, shareholders' protection, property rights, contract enforcement, democracy, political stability, corruption, belief, culture, races, and others. These variables reflect a country's institutional environment with certain effects on the economy through such fundamental factors as exchange rate, inflation, and so forth.

Accordingly, over the decades development of theoretical research has not come to a halt in an effort to discover the causes of currency crises. The models, due to being associated with specific crises, are not highly characteristic. Despite a series of newly introduced factors, they do not reject the existence of fundamental ones. Fourthgeneration models, for instance, verify the role the institutional environment factors, which exert their own impacts through effects on the primary ones.

\subsection{Empirical research}

As suggested by empirical investigations, the nature of currency crises is different in different countries (Kaminsky \& Reinhart, 1999). This can be explained by fundamental factors (first- and second-generation models), non-fundamental factors such as spillover effect (third-generation models), or institutional environment factors like protection for investors and corruption (fourth-generation models). In these empirical studies it is common that models of various generations are incorporated, defining the main causes of the crisis. They fit into two categories according to the used approaches: parametric and non-parametric.

The parametric approach depends mainly on regressions whereby the crisis variable is regressed to the selected components. Probit or logit models are often employed as econometric estimators, which treat crisis as a binary variable taking the value of 1 during the crisis and 0 if beyond, mostly in line with Kaminsky and Reinhart's (1999) technique. Using the data of 29 countries from May 1999 to December 2012, Comelli $(2013,2014)$ found that real GDP growth and net assets have positive effects on reducing the probability of a crisis, while credit growth of the private sector has the opposite impact. Comeli (2014) also demonstrated the similarity of results of probit and logit models.

Sachs et al. (1996) applied linear regression to the peso crisis in Mexico in 1994. To consider whether a country faces a currency crisis, the authors adopted three explanatory variables in the linear regression model, including percentage change in: (i) the exchange rate index; (ii) the ratio of size of claims of banking sector on private sector to GDP; and 
(iii) foreign exchange reserves. The dependent variable is the crisis index being weighted average of the percentage change in reserves and the devaluation rate in relation to the US dollar. Their findings attribute exchange rate appreciation, excessive lending, too low foreign exchange reserves, and short-term commitments that the central bank takes on to the crises.

For non-parametric approaches, the use of early warning indicators for currency stress suggested by Kaminsky and Reinhart (1999) is the most typical. These scholars proposed an approach based on the identification of whether several main economic variables tend to be abnormal before the crisis. The key idea is that if a signal is given by a variable and the crisis occurs within 24 months, this indicator is considered accurate, while in case of a signal yet no crisis within the given period, it is regarded as a false signal or noise. Applying this approach to inspect 76 currency crises and 26 banking crises in 20 developed and developing countries from 1970 to 1995, they detected a very close linkage between the crises and the later stage of financial liberalization. Furthermore, occurrence of the crisis coincides with economic recession, followed by a series of phenomena in the period of high economic growth such as excessive credit growth, cash inflows, and currency overappreciation. This approach was similarly adopted by Heun and Schlink (2004) for the case of Uganda. It was shown that the foreign exchange reserves, exchange rate, domestic credit, and credit to the public sector are the major factors to forecast the currency crisis besides trade balance, exports, money supply growth, real GDP growth, and budget deficit, which are also detected as early warning indicators.

Domestic works are confined to examination of macro effects on financial crises through qualitative evaluation along with comparison with other economies. One example is a study of Le (2008), which contrasted the Vietnam's economy and Asian ones over the 1996-1997 period by using economic growth and exchange rate. Limitations are revealed of both theoretical and empirical aspects when policy options are proposed. Pham et al. (2013) utilized the probit technique to study the early warning for currency crisis in Vietnam based on the macro factors employed as indicators with a focus on USD/VND exchange rates. In this investigation the dependent variable is a binary one, and the 1992-2011 period does not actually represent currency stress time in the country. Similar problems can also be reflected in another study conducted by Nguyen (2010). Using a sample of Vietnam, Indonesia, Malaysia, Thailand, and Philipines, Le (2015) adopted a non-parametric approach for estimating the model and 
calculating threshold levels for the case of Vietnam. The research phase, nevertheless, covers such a short length of time as the country's currency crisis period between March 2012 and February 2014 has brought about certain inaccuracy.

In short, review of theoretical and experimental studies exhibits different causes of monetary crises in different countries, yet early warning indicators for currency crisis may fall into four basic groups: (i) economic growth/output; (ii) openness of the economy, such as trade balance, exports, imports, and capital account; (iii) development of financial markets, such as credit, money multiplier, money supply (M1), and so on; and (iv) institutional environment.

During the study period (1996-2014), there were at times signs of the currency crisis, but thanks to timely intervention by the Government it was overcome, and the country was not truly faced with a crisis. In this paper we identify possible early warning indicators for currency crises in Vietnam, using the non-parametric approach in accordance with Kaminsky and Reinhart's (1999) technique as we are aware that for the parametric approach, the crisis variable as a dependent one mostly takes the value zero (i.e. no crisis), so no regression can be performed.

\section{Methods}

\subsection{Definition of currency crisis and estimation technique}

According to Heun and Schlink (2004), the currency crisis refers to the period which is marked by rapid currency depreciation or severely low foreign exchange reserves or both.

Kaminsky and Reinhart (1999) and Edison (2000) suggested measuring currency crisis through the currency crisis index (EMPI), which is the average of rate of change in exchange rate, $\delta e_{t}$, and rate of change in foreign exchange reserves, $\delta R_{t} . e_{t}$ is the exchange rate (US dollar/local currency) at time $t ; R_{t}$ is the foreign exchange reserves at time $t$ (in dollars); $\sigma_{\delta \mathrm{e}}$ is the standard deviation of the rate of change in exchange rate; $\sigma_{\delta \mathrm{R}}$ is the standard deviation of the rate of change in foreign exchange reserves. EMPI is measured as follows:

$$
E M P I_{t}=\delta e_{t}-\left(\frac{\sigma_{\delta e}}{\sigma_{\delta R}}\right) \bullet \delta R_{t}
$$


with

$$
\delta e_{t}=\frac{e_{t}-e_{t-1}}{e_{t-1}} \text { and } i R_{t}=\frac{R_{t}-R_{t-1}}{R_{t-1}}
$$

Since the rate of change in exchange rate (foreign exchange rate reserves) relates positively (negatively) to the currency crisis, the higher the EMPI, the greater likelihood there is of the crisis. In light of Kaminsky et al.'s (1997) argument, it occurs when the EMPI is $m$ times as great as the standard deviation plus the mean value. Let $\mu_{E M P I}$ be the mean and $\sigma_{E M P I}$ be the standard deviation of the crisis index; the currency crisis is defined as follows:

$$
\text { Currency crisis at time } t=\left\{\begin{array}{c}
1 \text { if EMPI }>\mu_{\text {EMPI }}+2 \sigma_{\text {EMPI }} \\
0 \text { otherwise }
\end{array}\right.
$$

\subsection{Identification of currency crisis determinants}

From the currency crisis models and empirical research results, the growth factors, those reflecting the openness of the economy and those reflecting the institutional environment, are suggested to possibly explain the crisis, and in the case of Vietnam these factors can be regarded early warning indicators. Slow economic growth may cause uncertainties to an economy. The higher the openness of the economy, the greater the dependence on the world economy, and thus it withstands greater spillover effects of the regional and global crises. Instability in the Vietnam's economy during 2008-2011 resulted significantly from the world's financial crisis in the same period. The problematic characteristics of financial markets, such as excess money supply and high interest rates, are also indicators of the currency crisis.

In this study we consider 14 determinants, categorized into four items that help explain the currency crisis, including current account, capital account, real sector, and financial sector indicators. Those belonging to institutional environment group are eliminated due to their common high stability, unsuitable for the non-parametric approach. On the other hand, data on the institutional environment of Vietnam in accordance with the World Bank's datascope are annual, and thus cannot be converted into monthly data as other types. The data in use are processed to fit the non-parametric technique as proposed by Kaminski and Reinhart (1999). 


\section{Table 1}

Early warning indicators of the currency crisis

\begin{tabular}{|c|c|c|}
\hline Item & Indicator & Definition \\
\hline \multirow{4}{*}{ Current account } & Real exchange rate ${ }^{1}$ & Deviations from trend \\
\hline & Exports & 12-month rate of change \\
\hline & Trade balance & 12-month rate of change \\
\hline & Imports & 12-month rate of change \\
\hline \multirow[b]{3}{*}{ Capital account } & Foreign exchange reserves & 12-month rate of change \\
\hline & $\mathrm{M} 2 /$ reserves ratio & Ratio of M2 to foreign exchange reserves \\
\hline & $\begin{array}{l}\text { Real interest rate } \\
\text { differential }\end{array}$ & $\begin{array}{l}\text { Domestic real interest rate compared to } \\
\text { US real interest rate }\end{array}$ \\
\hline Real sector & Real output & 12-month rate of change \\
\hline \multirow{7}{*}{ Financial sector } & M2 multiplier & 12-month rate of change \\
\hline & $\begin{array}{l}\text { Domestic credit/nominal } \\
\text { GDP ratio }\end{array}$ & Ratio of domestic credit to nominal GDP \\
\hline & Real deposit rate & Nominal deposit rate less inflation rate \\
\hline & $\begin{array}{l}\text { Lending rate/deposit rate } \\
\text { ratio }\end{array}$ & Ratio of lending rate to deposit rate \\
\hline & Excess real M1 balances & $\begin{array}{l}\text { M1 deflated by consumer prices less an } \\
\text { estimated demand for money }\end{array}$ \\
\hline & & (= M1x (1 - CPI/100) - money demand $)$ \\
\hline & Bank deposits & 12-month rate of change \\
\hline
\end{tabular}

The data are retrieved from IMF International Financial Statistics (IFS) and General Statistics Office of Vietnam (GSO) databases. All data are monthly except for GDP and output which are quarterly data, for which conversion into monthly data is undertaken with assumption about periodic increases over the months. 


\subsection{Non-parametric approach}

Given the non-parametric approach, the study of Kamisky and Reinhart (1999) is one typical example, suggesting identification of abnormality of the key variables before the crisis.

To predict the crisis each factor is analyzed independently. If it exceeds a certain threshold level, it is regarded as a signal of the crisis. Assuming that $X$ is a vector of $n$ factors $(\mathrm{n}=14), X_{t, j}$ denotes the value of the factor $j$ at time $t$. Thus, the crisis indicator relative to each factor can be defined as follows:

$$
S_{t, j}=\left\{\begin{array}{c}
1 \text { if } X_{t, j} \text { exceeds a certain threhold } \\
0 \text { otherwise }
\end{array}\right.
$$

In this paper we also obtain our threshold determination results from Kaminsky and Reinhart (1999), Edison (2000), and Goldstein et al. (2000). The selected threshold is the mean of the results as achieved by those three studies. These findings are considered due to: (i) high generality of the datasets; and (ii) their similarity and very small standard deviations. Therefore, using the average value is expected not to cause a significant alteration to them.

Kaminsky and Reinhart (1999) documented that in all countries the threshold value of each factor is determined by percentiles of the distribution of observations. Thus, the absolute value of the threshold for countries is different. It was noted that for some factors the upper tail of the distribution indicates the crisis, whereas for others it is the lower tail that is found to issue a warning. The following table provides comparisons and the threshold value of each indicator.

\section{Table 2}

Threshold values of indicators and comparisons

\begin{tabular}{lcc}
\hline Indicator & Relative to the threshold & $\begin{array}{c}\text { Threshold value } \\
\text { (percentile of the distribution) }\end{array}$ \\
\hline Real exchange rate & Lower & 0.10 \\
Exports & Lower & 0.10 \\
$\begin{array}{l}\text { M2/foreign exchange } \\
\text { reserves }\end{array}$ & Upper & 0.11 \\
Output & Lower & 0.11
\end{tabular}


Indicator

Relative to the threshold

Threshold value

(percentile of the distribution)

\begin{tabular}{lcc}
\hline Excess real M1 balances & Upper & 0.09 \\
Foreign exchange reserves & Lower & 0.12 \\
M2 multiplier & Upper & 0.13 \\
Domestic credit/nominal & Upper & 0.11 \\
GDP & Lower & 0.13 \\
Trade balance & Upper & 0.13 \\
Real deposit rate & Upper & 0.10 \\
Imports & Upper & 0.11 \\
Real interest rate differential & Upper & 0.17 \\
Lending-deposit rate & Lower & 0.12 \\
Bank deposits & . & \\
\hline
\end{tabular}

According to Kaminsky (1999) and Heun and Schlink (2004), if there exist more indicators of the crisis, the likelihood of the crisis will be greater. The composite index, as measured by the weighted average of the signals of each indicator with the weights being the inverses of the noise-to-signal ratio, allows for better identification of the crisis, compared to each indicator in isolation. The index is defined as below:

$$
S_{t}=\sum_{j=1}^{n} \frac{1}{\omega_{j}} S_{t, j}
$$

where $S_{t, j} \in\{0,1\}$ denotes the signal of the indicator $j$ (it crosses the threshold at time $t$ or not) and $\omega_{\mathrm{t}}$ is the noise-to-signal ratio of indicator $j$, which is the mean of the attained results of Kaminsky and Reinhart (1999), Edison (2000), and Goldstein et al. (2000).

To estimate the probability of the crisis using the composite index, we adopt the probability results in Kaminsky (1999) and Goldstein et al. (2000). The range of the composite index is converted into conditional probabilities through linear transformation as illustrated in Table 3. 


\section{Table 3}

Probabilities of the currency crisis in accordance with the composite index

\begin{tabular}{cc}
\hline Value of index S & Probability of the crisis \\
\hline $0-0.8$ & 0.10 \\
$0.8-1.5$ & 0.22 \\
$1.5-2.3$ & 0.18 \\
$2.3-3.1$ & 0.21 \\
$3.1-3.8$ & 0.27 \\
$3.8-5.4$ & 0.33 \\
$5.4-6.9$ & 0.46 \\
$6.9-9.2$ & 0.65 \\
$9.2-11.5$ & 0.75 \\
Above 11.5 & 0.96 \\
\hline
\end{tabular}

\section{Empirical results}

Figure 1 plots the currency crisis indicator EMPI. As shown, in the period from 1996 to 2014 the Vietnam's EMPI crossed the threshold six times, indicating six warnings of the currency crises in November 1997, August 1998, July 2008, January 2009, March 2010, and February 2011. These periods marked increases in the USD-VND exchange rate yet reduction in foreign exchange reserves. In the years 2009 and 2010, the country's economy was strongly affected by the global financial crisis. At the beginning of February 2011 the index crossed the threshold more significantly than it did for the remaining years due to the depreciation of VND against USD (down $7.3 \%$ ) and the decrease in foreign exchange reserves of $1.6 \%$. 


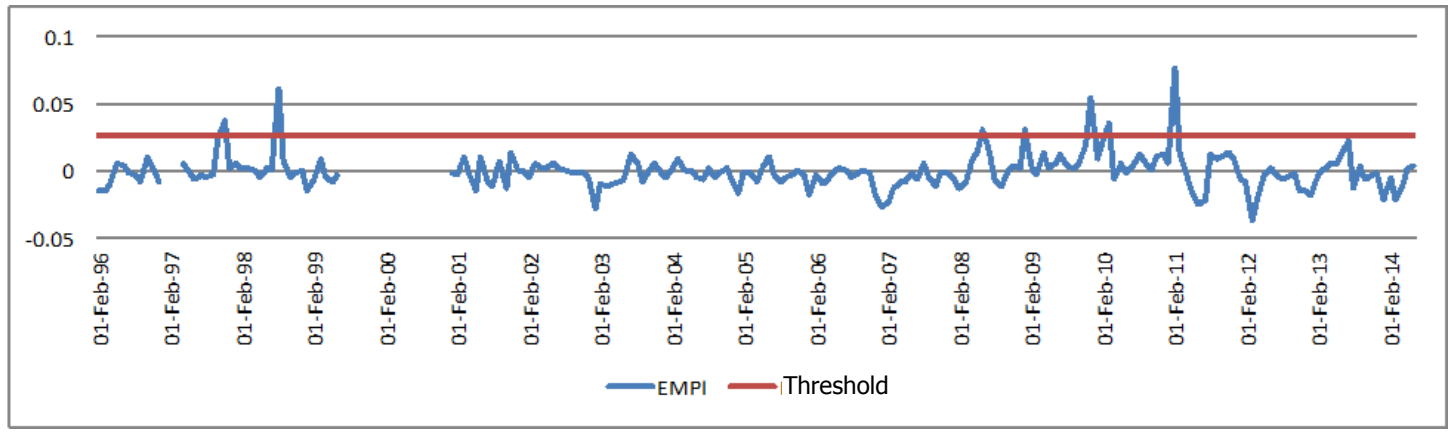

Figure 1. The Vietnam's EMPI during 2002-2014

Figures 2 and 3 show the composite index and probability of the currency crisis in Vietnam between 2005 and 2013. Consistent with the results of Figure 1, the years 2008, 2009, 2010, and 2011 indicated rather high probabilities of the crisis.

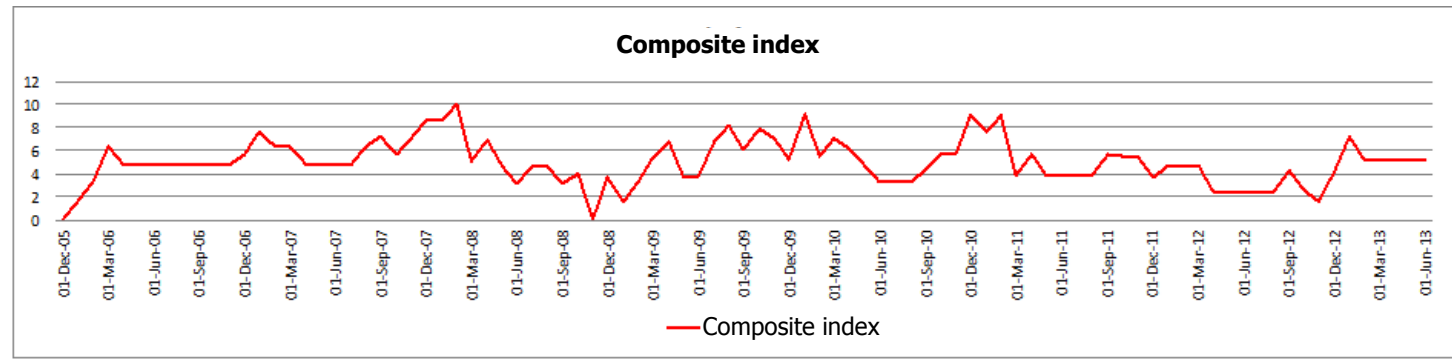

Figure 2. The Vietnam's composite index during 2005-2013

Source: Authors' calculations using IMF statistics

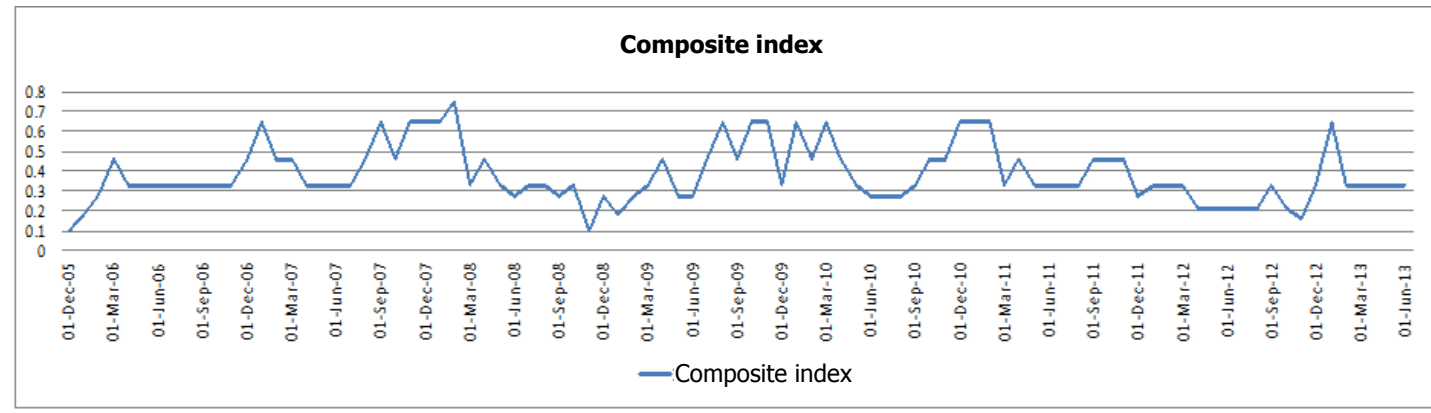

Figure 3. Currency crisis probabilities in Vietnam during 2008-2013

Figure 4 illustrates comparisons between 14 indicators and their corresponding thresholds. The analytical results of these indicators and EMPI confirm the possibility of their early warning of the currency crisis. 

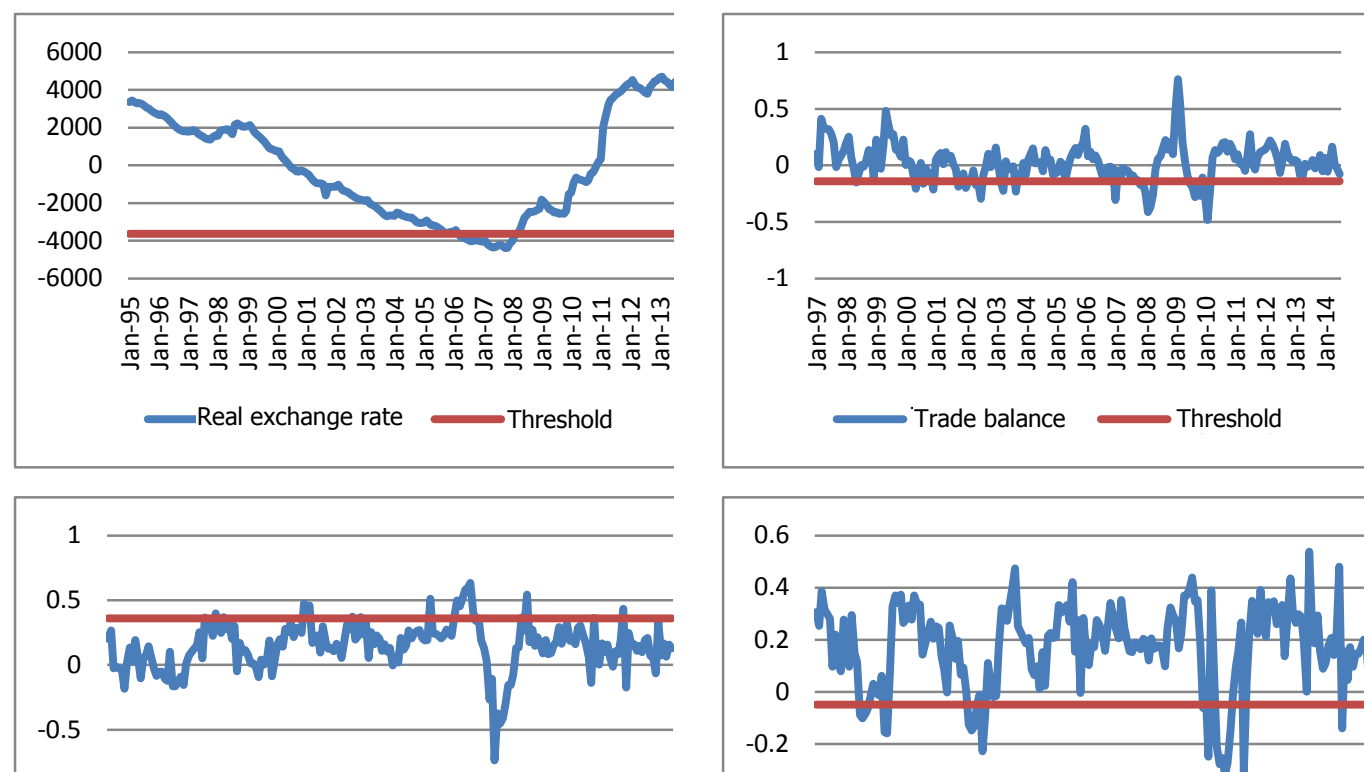

$-1$

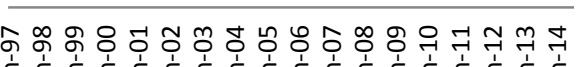

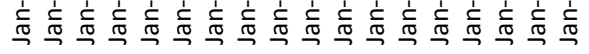
Imports Threshold
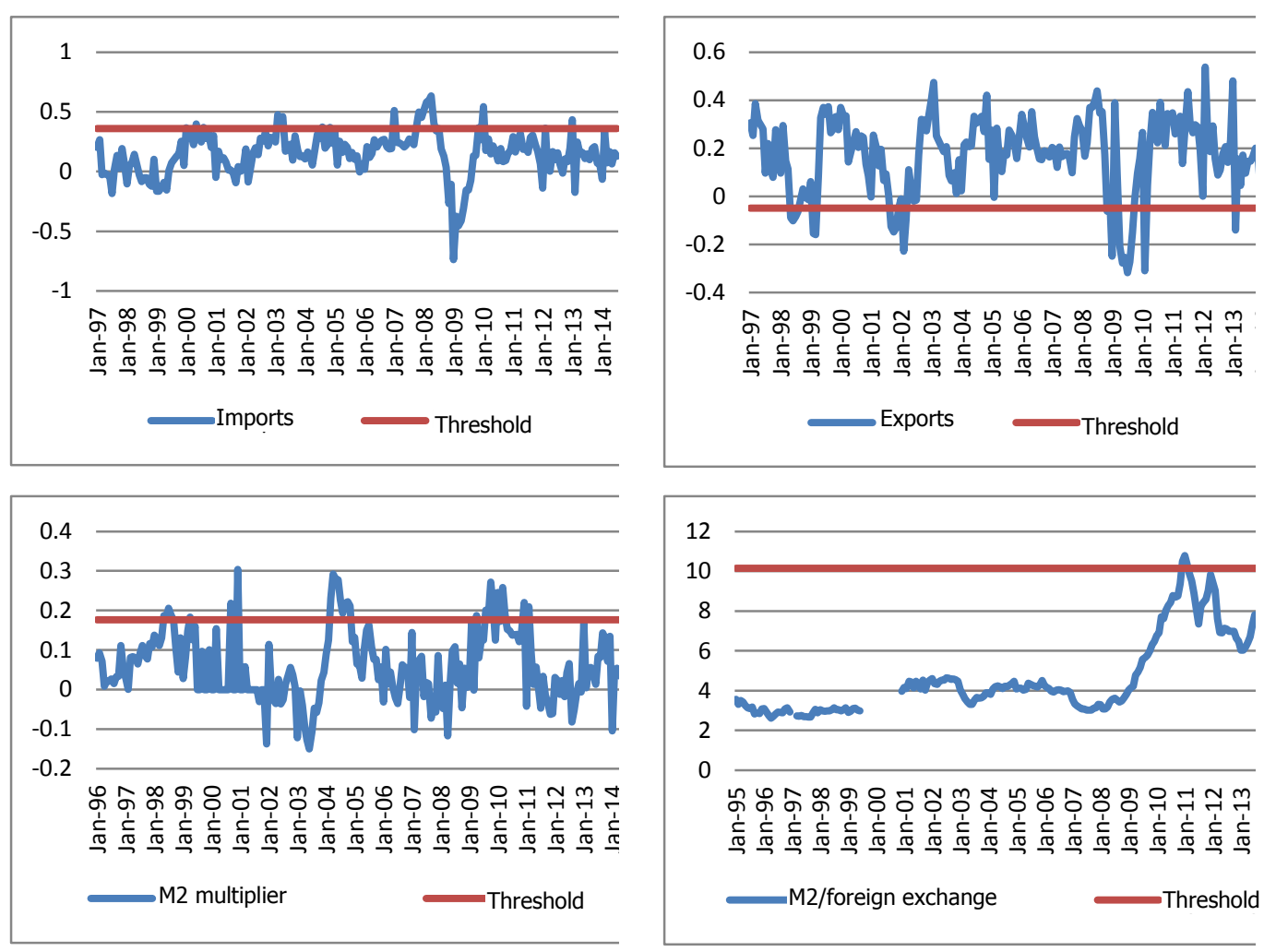

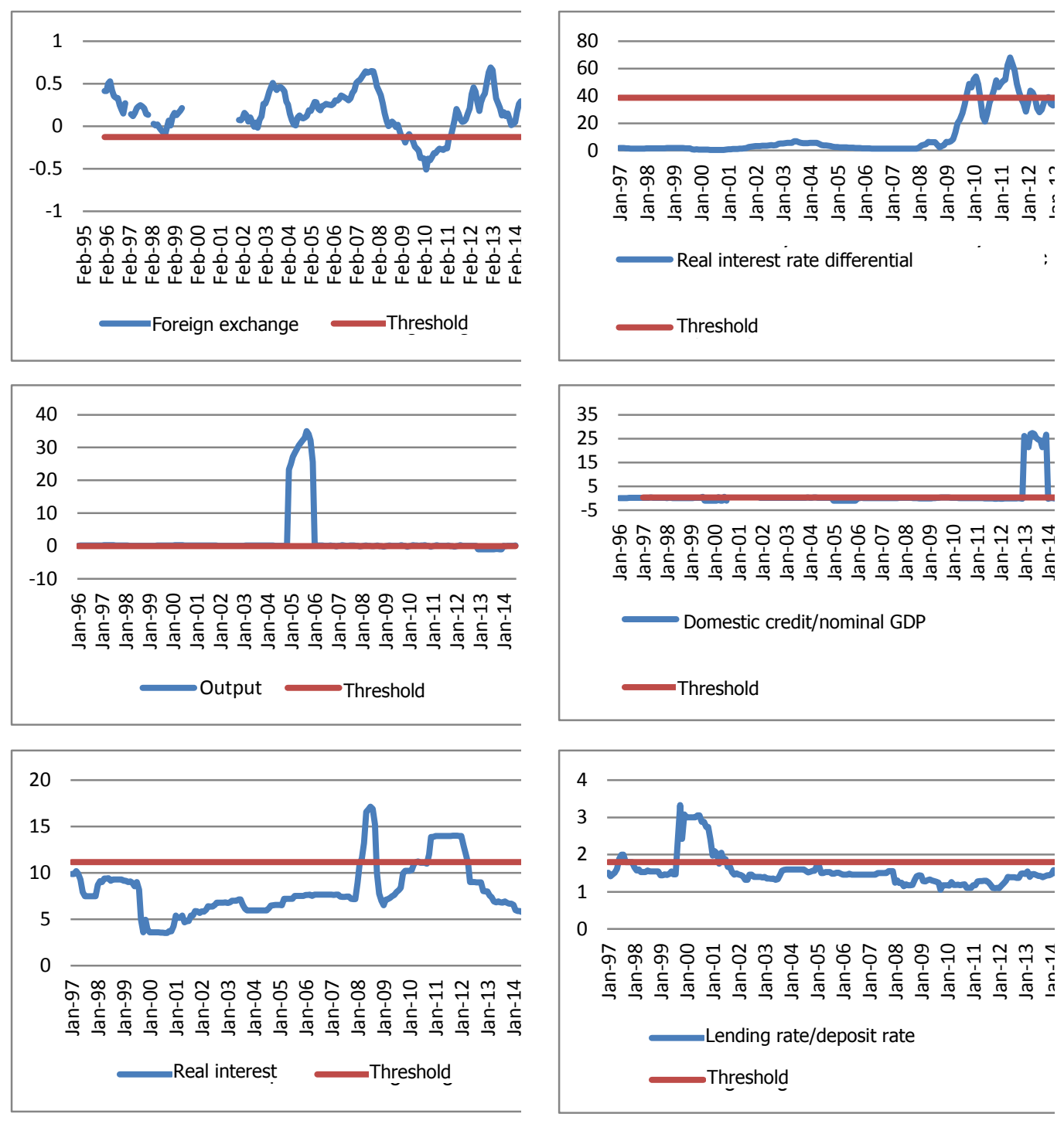

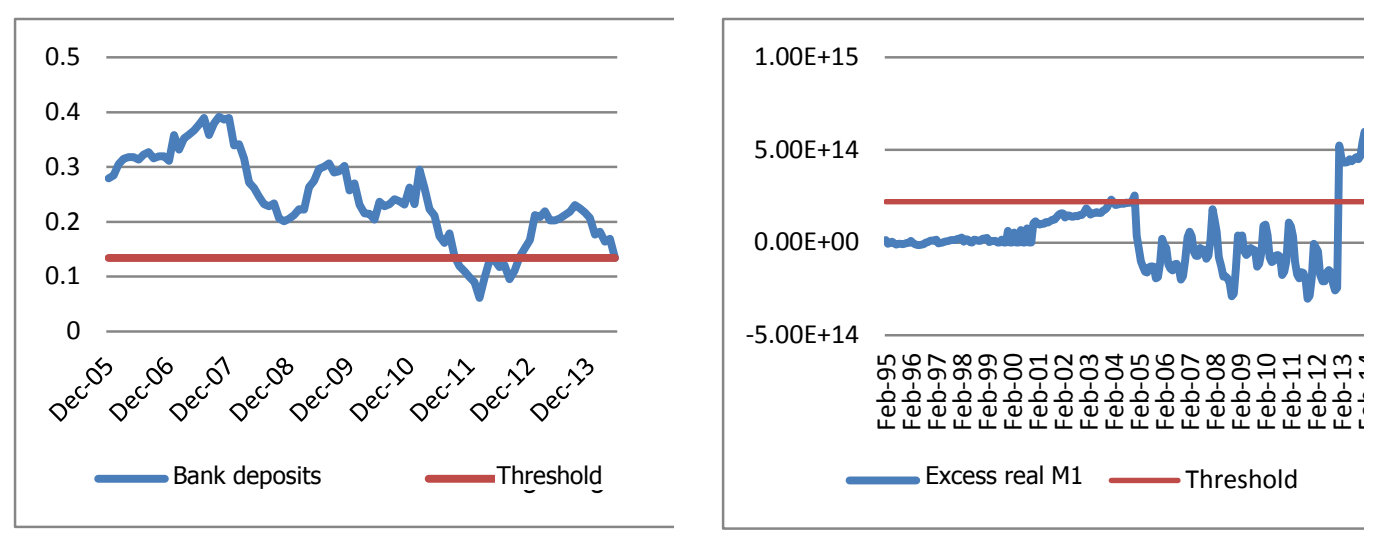

Figure 4. Early warning indicators of the currency crisis

Source: Authors' calculations using ADB and WB statistics

In the 1997-1998 period the economy of Vietnam experienced the spillover effect of the financial crisis in East Asia. Economic fluctuations of the years 1997 and 1998 were recorded with the three indicators crossing the thresholds, including real output, exports, and ratio of lending rate to deposit rate. Specifically, according to the results of the crisis index, EMPI exceeded the threshold as of November 1997 despite no threshold-crossing cases of any indicators in the same month. However, in the first ten months of 1997, real GDP growth slowed down and was lower than the threshold. The ratio of lending rate to deposit rate increased and crossed the threshold during June-August 1997. The year 1998 was perceived as a follow-up to economic decline, and currency crisis was warned in August 1998. Particularly, in May-August 1998 exports dropped by 8-10\% compared to those of the same period of the previous year; the trade deficit was minus USD229 million; the M2 multiplier increase exceeded the threshold. Other factors, such as trade balance, imports, and foreign exchange reserves, despite not regarded as similar cases, almost reached the threshold levels due to the impact of the economic crisis.

The 2000-2002 period started with the global recession, including the significant economic slowdown in the US, mainly owing to great depreciation of the stocks in the sectors of information technology and telecommunications since March 2000 and the terrorist attacks on September 11, 2001. Vietnam's economic performance was also affected radically by this recession period. In early 2000 imports increased by $35-40 \%$ compared to those at the end of 1999, causing a trade deficit. The trade balance exceeded the threshold by end-2000. In 2001 the import growth rate decreased, so did the export 
growth rate, and there remained the trade deficit crossing the threshold in the period from October 2001 through July 2002. Also in the 2000-2001 period the lending rate was constantly $2.5-3$ times as high as the deposit rate, while the necessary threshold was merely 1.8 .

After a period of economic stability of 2003-2006, by end-2006 probability of a crisis in Vietnam increased by $46 \%$, it reached $65 \%$ by January 2007 due to the emergence of several warning indicators, such as real exchange rate, imports, and trade balance. 2007 was the first year of the country's WTO accession, opening up a series of opportunities. However, the biggest challenge in implementing the monetary policy of the State Bank in 2007 was at a high level of the trade deficit of approximately USD600 million. Specifically, between October 2007 and May 2008 imports exceeded its threshold, entailing the trade deficit during November 2007-April 2008. Foreign capital inflows increased sharply; inflation had a tendency to rise substantially amid global financial market fluctuations that placed pressure on the exchange rate governance and control over the total means of payment and credit.

Since early 2008 the central bank had been employing tightened monetary policy to curb inflation by: (i) increasing required reserves and enhancing reservable deposits for all terms; (ii) issuing treasury bills worth VND20,300 billion with regulation that the central bank's bills must not be used for refinancing at the central bank; and (iii) adjusting the base rate to $12 \%$ and then $14 \%$ and adjusting the operating interest rate including the pair of refinancing rate to $15 \%$ and 13\%; and (iv) controlling the credit limit and placing strict control over high-risk loans, particularly loans for securities and real estate investments. In 2008 although the global economy went into recession due to the impact of the US financial crisis, the currency crisis probability of Vietnam was kept at low levels $(27-33 \%)$ or was even as low as $0.18 \%$ thanks to the promptly and flexibility implemented policies as discussed.

The period between late 2008 and early 2009 revealed the country's economic decline. Figures 2 and 3 show that during the last months of 2009 and early 2010 the probability of a crisis in VN was constantly high at $65 \%$ and $46 \%$, consistent with the EMPI results. Comparing to the graphs in Figure 4, in the 2009-2010 period six factors exceeded the thresholds, including exports (March-August 2009), balance of trade (July-November 2009), interest rate differential (October 2009-March 2010), real interest rate (April-May 2010 and October-December 2010), and especially foreign 
exchange reserves constantly declining and crossing the threshold during 2009 and 2010. Specifically, in March 2010, when EMPI exceeds the threshold, the crisis was signaled with reduction in the trade balance and foreign exchange reserves as well as higher domestic interest rate than that of the foreign country and M2 multiplier crossing the threshold. These factors contributed to the highest increase in the crisis probability over the study period.

In early 2009 to respond to the global recession and maintain economic growth the Government launched stimulus packages totaling approximately VND150,000 billion including support for $4 \%$ interest rate, consumption, and investment in basic constructions. These serial packages, as well as the sale of foreign currency to stabilize the exchange rate, resulted in a reduction in foreign exchange reserves of $31 \%$ in 2009 and increase in the ratio of domestic credit to GDP that exceeded the threshold. The rising interest rate was also attributed to increase in crisis probability of $65 \%$ during late 2009 and early 2010, which suggests a clear association between the packages and a double-edged sword, in which any improper use would cause far-reaching consequences. Positive results, nevertheless, were obtained as the packages could create an economic push in the context of stagnation and decline, thereby achieving social consensus and appreciation. By May 2010 and August 2010 the crisis probability reduced to $33 \%$ and $18 \%$ respectively. However, it returned to the level of $46 \%$ in early 2011 due to low foreign exchange reserves and bank deposits yet high ratio of M2 to foreign exchange reserves and relatively high interest rate differential. In February 2011, EMPI crossed the threshold besides the signals issued by increased M2 multiplier, decreased reserves, increased $\mathrm{M} 2 /$ reserves, increased interest rate differential, and increased bank deposits.

There existed rather low levels of crisis probability during 2011-2012, but it increased to 65\% in January 2013 when there were signals of the currency crisis among such four factors as exports, ratio of domestic credit to nominal GDP, output (decrease of $97 \%$ compared to the same term of previous year), and excess real M1 balances (VND 524,000 billion).

Overall, there were six times when Vietnam's economy was shown to suffer the currency crises. Several principal causes lie in the effects of regional and global ones in addition to the extant downsides of the national economy like explosive credit growth that was conducive to excess M1 balances, low real output growth, abnormal inflation, 
and unsustainable production. Still, timely intervention of the Government and the State Bank has allowed these instabilities to be effectively controlled despite many radical challenges posed by global fluctuations and Vietnam's greater integration into the world.

\section{Conclusion and recommendation}

\subsection{Conclution}

As indicated by increases in EMPI in late 1998, mid 1998 and 2008, early 2009, early 2010, and early 2011, there were a total of six times when the currency crisis was signalled. This result is in line with calculations using the composite index and crisis probability.

The findings also demonstrate the main currency crisis indicators over the recent period including increased imports, reduced exports, excess real M1 balances, low deposit growth, high domestic real interest rate (higher than the foreign real interest rate), too high lending rate compared to deposit rate, decreased foreign exchange reserves, overheated credit growth, and reduced output. The Government and policy makers, therefore, need to take account of these factors for proper interventions in case of any crisis signals issued by them (i.e. when they cross the threshold levels) to mitigate and/or avert possible monetary crises.

\subsection{Recommendations}

The factors such as excess real M1 balances, deposit growth, credit, interest rate, and output are shown to be likely to cause a currency crisis. Thus, the Government and the State Bank should adopt sound policies to control the money supply and interest rate and to assure a reasonable deposit growth, thereby contributing to economic growth. However, this is such a great puzzle as a tightened monetary policy to respond to those problems may negatively affect deposit growth and economic output. To attain both of these objectives, it is imperative to monitor rigorously the degree of volatility of these factors with necessary interventions when a threshold-crossing event occurs.

Openness of the economy (exports and imports) and foreign exchange reserves are also two determinants of the monetary crisis in Vietnam. The impacts of regional and global crises via exports and imports are inevitable. To minimize these effects support should be given to importers and exporters in diversifying their markets in order to avoid 
being heavily dependent on a few partners. Additionally, these enterprises should be encouraged to be insured against adverse impacts of those crises.

Since this study was conducted during 1996-2014, which was the period of many economic volatilities, its findings are believed to provide an overview on the possibility of the currency crisis as well as its indicators. However, data constraints have caused the sample not to have total temporal consistency: a short period from 2005 to 2013 was applied to the composite index and crisis probability, whereas given the others the surveyed period was between 1996 and 2014. Further research is expected to be carried out for a larger sample and expand the scope to ASEAN countries and many others

\section{Notes}

${ }^{1}$ The exchange rate between USD and VND

${ }^{2}$ The ratio of noise to good signal; good signal refers to the factor crossing the threshold within 24 months prior to the crisis, while false signal or noise denotes the factor which exceeds the threshold, but within 24 months no crisis occurs.

\section{References}

Acemoglu, D., Johnson, S., Robinson, J., \& Thaicharoen, Y. (2003). Institutional causes, macroeconomic symptoms: Volatility, crises and growth. Journal of Monetary Economics, 50(1), 49-123.

Breuer, J. (2004). An exegesis currency and banking crises. Journal of Economic Survey, 13(3), 293328.

Chang, R., \& Velasco, A. (1998). Financial crises in emerging markets: A canonical model. NBER Working Paper No. 6606. MA: National Bureau of Economic Research.

Chang, R., \& Velasco, A. (2001). A model of financial crises in emerging markets. The Quarterly Journal of Economics, 116(2), 489-517.

Corsetti, G., Pesenti, P., \& Roubini, N. (1999). Paper tigers? A model of the Asian crisis. European Economic Review, 43(7), 1211-1236.

Edison, H. J. (2000). Do indicators of financial crises work? An evaluation of an early warning system. International Financial Discussion Paper No. 675. Washington, DC: Board of Governors of Federal Reserve System.

Goldstein, M., Kaminsky, G. L., \& Reinhart, C. M. (2000). Assessing financial vulnerability: An early warning system for emerging market. Washington, DC: Peterson Institute for International Economics. 
Heun, M., \& Schlink, T. (2004). Early warning systems of financial crises: Implementation of a currency crisis model for Uganda. Frankfurt School Working Paper Series No.59. Frankfurt am Main, Germany: Business School of Finance \& Management.

Johnson, S., Boone, P., \& Breach, A. (2000). Corporate governance in the Asian financial crisis. Journal of Financial Economics, 58(1-2), 141-186.

Kaminsky, G. L. (1999). Currency and banking crises: The early warnings of distress. Working Paper No.99/178. Washington, DC: International Monetary Fund.

Kaminsky, G. L., \& Reinhart, C. M. (1996). The twin crises: The causes of banking and balance of payment problems. International Finance Discussion Paper No.54. Washington, DC: Board of Governors of Federal Reserve System.

Kaminsky, G. L., \& Reinhart, C. M. (1999). The twin crises: The causes of banking and balance of payment problems. American Economics Review, June(1999), 473-500.

Kaminsky, G. L., Reinhart, C. M., \& Lizondo, S. (1997). Leading indicators of currency crises. Working Paper No.97/79. Washington, DC: International Monetary Fund.

Krugman, P. (1979). A model of balance-of-payments crises. Journal of Money, Credit and Banking, 11(3), 311-325.

Krugman, P. (1998). Are currency crises self-fulfilling? NBER Macroeconomics Annual 1996, Volume 11. MA: MIT Press.

Le, T. T. V. (2013). Application of an early warning model for currency crises in Vietnam (in Vietnamese). Hanoi, Vietnam: National Institute for Finance.

Le, V. A. (2008). Financial crisis: Theoretical framework and risks to Vietnam in its current course of integration (in Vietnamese). Retrieved from http://tapchi.vnu.edu.vn/1_208_KTluat/7.pdf

Nguyen, P. L. (2010). Early warning model and policies toward macroeconomic stability (in Vietnamese). Hanoi, Vietnam: State Bank of Vietnam.

Obstfeld, M. (1986). Rational and self-fulfilling balance-of-payment crises. American Economic Review, 76(1), 72-81.

Pham, T. H. A., Nguyen, H. N., Bui, D. P., Nguyen, T. H. H., Ha, T. S., Nguyen, T. M. N., ... Le, H. T. (2013). Adopting early warning system approach based on forex exchange stress index in Vietnam to manage foreign exchange and monetary policy (in Vietnamese). Retrieved from http://nckh.hvnh.edu.vn/upload/5830/fck/files/Extract\%20Pages\%20From\%2023_\%20De\%20ta i\%20mo\%20hinh\%20canh\%20bao\%20som.pdf

Sachs, T., Tornell, A., \& Velasaco, A. (1996). Financial crises in emerging markets: The lesson from 1995. Brookings Papers on Economic Activity, 1:1996, Brookings Institution. Retrieved from https://www.brookings.edu/wp-content/uploads/1996/01/1996a_bpea_sachs_tornell_velasco_ calvo_cooper.pdf 